\title{
The Empire of the Senses Police as Art and the Crisis of Representation
}

Hito Steyer ${ }^{1}$

\footnotetext{
1 Hito Steyerl is professor for experimental film and video and the co-founder of the Research Center for Proxy Politics at the Berlin University of the Arts. She studied cinematography and documentary film in Tokyo and Munich and wrote her doctoral thesis at the Academy of Fine Arts in Vienna. Her research focuses on media, technology and the distribution of images. In her texts, performances and essayist documentary films Hito Steyerl deals with postcolonial criticism and feminist criticism of representational logic. She works at the intersections of visual art and film as well as theory and practice. Her numerous works have been exhibited at the most prominent global art institutions, such as the Venice Biennale, the Museum of Contemporary Art, Los Angeles and the Museum of Modern Art, New York. In addition to her work as an artist she was a lecturer at the Center for Cultural Studies at the Goldsmith College in London and a guest professor at the Royal Academy of Copenhagen and the Academy of Fine Arts, Helsinki. The Royal College of Art, London, honored her in 2016 with an "Honorary Doctorate".
} 
The film In the Realm of the Senses by Oshima Nagisa from 1976 is a brillant example of how art has traditionally been policed. The film is based on the real story of Abe Sada, who killed her lover in the 1930s after a passionate love affair. Oshima's version of the story used such explicit sexual content, that the footage had to be sent to France in order to be developed, since no Japanese lab would touch it. Shortly before it was premiered at the Berlin film festival, the print was seized and confiscated as "hardcore pornography". In Israel its ban was only lifted by the Supreme court. Its scenes of violence and automated sexuality were generally and even globally understood as an attack on morality and as a transgression of social norms. Traditionally policing in art took on precisely the function of preventing this transgression: it implemented censorship. The realm of the senses was something that had to be repressed, because it seemed threatening and potentially liberating. Explicit sex was part of it.

But now the situation is reversed. In Abu Ghraib, pornography has become a tool of the police, consciously used for degradation and submission. Explicit sex scenes no longer threaten power, but multiply it. The realm of the senses has been transformed into the Empire of Senses, and sensuality and even hardcore pornography create and maintain this Empire. But the events of Abu Ghraib are just an extreme example of a general enlistment of the senses into domination. In an era dominated by fear and sensation, power operates more than ever within the senses. It is increasingly sensible, it has penetrated perception as such, it has become overwhelmingly aesthetic. In the Empire of Senses, politics are not merely aestheticised, but exercised as aesthetics. The Empire of Senses is built on shock and attraction, on desire and disgust, on hatred and hysteria, on feeling and fear. The power to trigger, channel, mediate and market those emotions is a characteristic of contemporary power as such.

\section{From Signs to Senses}

Of course, if we follow Jacques Rancière's distinction between politics and police, ${ }^{2}$ we must admit, that this type of politics is not politics at all. It is policing. The aesthetics of the Empire of Senses are an aesthetics of

\footnotetext{
2 Jacques Rancière: Disagreement, Politics and Philosophy, Minnesota: University of Minnesota Press 1998, p.29.
} 
the police. But the activities of police have profoundly changed. While In the Realm of the Senses was censored in 1976, the police are now acting themselves as pornographers. The transition from one constellation to the other, from the repressed "Realm of the Senses" to the hegemonial "Empire of Senses" is also evidenced by the various meanings of the title of Oshima's film: In the Realm of the Senses is the incorrect translation of the French title L'empire des Sens. Both titles try to territorialize the realm of the senses in the realm of the Other, in this case Japan. The original Japanese title does the same though: Ai no corrida (The bullfight of love) plays with the exotic connotation of Spanishness.

Spain is conjured up as as the location of deadly passion and hormones running amok. The senses are always already located in the realm of the Other. But the most important displacement wasn't a geographical one. It wasn't so to speak quantitative, but qualitative. The French titling of the film was most probably coined after Roland Barthes's popular orientalizing booklet inspired by Japan: L'empire des Signes (The Empire of Signs), published in 1970.

In 1976, through creative translation the empire of signs was recast as the Empire of the Senses. From the signs to the senses: this shift mirrors the change of address of power, its arena of play. And since 1976 we have seen, how power increasingly ventures outside of the realm of written law or traditional discourse into the less charted waters of pure feeling. Feeling is increasingly politicized and commodified. Desire is drafted into production, and fear becomes the contemporary form of the public. The displacement from signs to senses in Oshima's film title evidences the shift from power as a discursive tool, to power as a quality of perception, the shift of balance from power as representation to power as feeling or affect. $^{3}$

\section{Power / Affect}

The contemporary conjunction of power and affect is so obvious that we could speak of a combined notion of power / affect in analogy to Foucault's notion of power/ knowledge. ${ }^{4}$ The growing importance of

\footnotetext{
${ }^{3}$ This is not to say, that one has been replaced by the other, but only that the balance of power has shifted and its tools have been expanded.

${ }^{4}$ For example in Michel Foucault, The History of Sexuality, vol. 1, Harmondsworth: Penguin, 1981. pp. 92 - 102.
} 
power / affect is not only evidenced by the fact that the Japanese sex industry is no longer a marginal and locally restricted place as in Abe Sada's times. It has broken its boundaries and is currently about to overtake the car industry as the most important industrial sector in Japan. ${ }^{5}$ Power / affect fuses sensation, desire, commodity fetishism and extreme domination into a neverending volley of serialized shocks. One interesting example of such a combination is a fashion spread in the Italian Vogue of Fall 2006, called: "The State of Exception."6

State of exception is a fashion stint by American photographer Steven Meisel, which takes pictures from Abu Ghraib and antisummit demonstrations as well as security checks, searches, and arrests as its inspiration. Young models wearing Yves St. Laurent clutches are facing sexual harassment during arrest. They imitate poses from the Abu Ghraib pictures, while the caption lists the names of haute couture designers. The series manages to simultaneously capture the fear and attraction of terror, glamor, S \&M pornography, and brand voyeurism. It demonstrates how an Empire of the Senses creates and sustains itself: by arousing, channelling and commodifying sensation, and by turning the exception into prêt-à-porter fashion lines.

\section{Rhythm of catastrophe}

But power / affect also pervades perception in a less obvious, but much more important way. Not only the content, but also the form of these economies of affect is pornographic. Contemporary news evoke a situation of constant exception, a crisis in permanence, a state of heightened alert and tension. Their rhythm structurally reproduces the form of Oshima's film, whose violence mainly consists of the fact that its sex is shockingly monotonous, repetitive and infinite. This has become the pattern of contemporary media, with their neverending repetition of catastrophe, transgression and intimacies. The Empire of Senses is no longer the exception, which has to be policed and repressed, but has become the contemporary norm of perception.

\footnotetext{
5 Alex Pappas, Japan's sex trade is cleaning up and cleaning house, in: http://japundit.com /archives/2006/10/28/3952/ 10/28/2006. Date of citation: 26.6.07

${ }^{6}$ Steven Meisel The State of Exception in: Vogue Italia, September 2006
} 
The current politics of fear have added a whole new dimension to this scenario. With the introduction of permanent terror alerts, the red light zone has now broken its boundaries and flooded the whole world. In the age of permanent alarm, the red light district is everywhere.

As Brian Massumi has argued, the terror alert system is an instrument to synchronize the affects of the American population. There is no need for explanations anymore - just flash a color at the people (anything between red and yellow that is; green is not an option) and modulate their moods. ${ }^{7}$ Fear is the LSD of the present. Fear is addictive and also attractive. Fear has lots of qualities we like.

It is intense, abundant, it multiplies, unlike people it travels freely and swiflty. Similar to digital information it can be copied not only without loss of quality but even substantial improvement. It is subject of intense enjoyment, a paradoxical desire in disguise. Fear feels real - unlike reality itself.

But fear is more than that. In the Empire of Senses, it is a popular commodity form of affect; it is branded, appropriated, marketed, maybe even franchised. The shiver of the attractions of the vanity fair, the shock of hardcore porn, the special effects of angst and trepidation are being mass produced by media machineries and coated with readymade reality. Paolo Virno has reminded us, that this pervasive and existential fear is linked to the loss of traditional community and the nascent state of the crowd. It cannot be contained by common ritual or its modern counterpart: a public sphere of communicative rationality. ${ }^{8}$ On the contrary: fear itself is the form of the contemporary public. It constitutes a widely globalized common, swaying with the rhythm of breaking news.

\section{Politics of the Monochrome}

In the Empire of Senses, police becomes an expert in aesthetics. The colors of the terror alert system are just one example of how the police paints moods and atmosphere. A strategy, which has a long tradition in

\footnotetext{
7 Brian Massumi, Fear- (The Spectrum said) in: http:// www.16beavergroup.org/mtarchive /archives/001927.php. Date of quotation: 26.6.07

8 Paolo Virno, Grammatik der Multitude. Vienna: Turia und Kant 2005. p. 37 ff.
} 
monochrome paintings. But adopting the aesthetic strategies of the monochrome is not confined to terror alerts, but has become a trademark of postpolitical aesthetics. Just think of the series of recent color revolutions: the rose revolution in Georgia (2003), orange revolution in Ukraine (2004), green or Cedar Revolution in Lebanon (2005). Even the presumed "coming of democracy" to Iraq after the elections in 2005 was briefly called the "purple revolution" The name comes from the color that voters' index fingers were stained to prevent illegal multiple voting. The "blue revolution" was the name of the protests of Kuwaiti women to gain the right to vote in the 2007 parliamentary elections. ${ }^{9}$ In each case, the connection with a particular color was sufficient to evoke feelings of hope or fear within the public regardless of any political content. The color became a brand name for a specific political affect instead: a politics of the monochrome.

But what is this politics of the monochrome based on? Let's explore this specific type of political aesthetics further. It is clear that the monochrome is a genre with a long tradition in modernity. What was the function of the monochrome when it first appeared in the art world? Right from the start a strong contradiction arises within the interpretation of monochromes. In 1921, Alexandr Rodchenko exhibited three monochromes together - each in one of the three primary colors. He intended this work to be a manifestation of "the death of painting." In contrast to that, Kazimir Malevich's White Square on a White Field of 1918 was rather understood to be a concentration on the essence of art ("pure feeling"). The monochrome could thus be interpreted either as the end of art or as "pure feeling"; as the "death of painting" or as completely new beginning in art.

The function of political monochromes is very similar. They both signify the end of politics as such (end of history, advent of liberal democracy) and at the same time an era of "pure feeling" which is heavily policed. They signal simultaneously the death of politics and its radical renewal on the level of perception. Political monochromes and omnipresent red alerts both generate fear and excitement, and a concentration on sensation. As banners of the Empire of Senses, they amazingly catalyze massive political identification and emotion without any apparent political content - by appealing on "pure feeling".

\footnotetext{
9 Information from Wikipedia entry: Color revolutions, in: http://en.wikipedia.org/wiki/Color_revolutions. Date of quotation 26.6.07
} 


\section{Crisis of Representation}

But the monochrome as form also points to another development. In the Western art history of the 20th century the monochrome manifests a crisis of representation, which ultimately brings about the destruction and leaving behind of the traditional form of panel painting as such. Artists freed color, form and ultimately the objects from the confine of the frame. The frame was attacked, exposed, destroyed, and later simply left behind. ${ }^{10}$

Does the appearance of the political monochrome, almost a century later, not point out a similar "crisis of representation" in politics? It seems, as if we were slowly leaving behind the framework of the democratic nation state, as we left behind the frame of the traditional panel of the painting. But it seems as beyond the traditional frame of politics - the nation state - there was just the chaos of "pure feeling": fear, colors, various intensities, tightly controlled flows, and repetitive sensation. The Empire of Senses is a space where laws may apply or not, where anything may happen anytime.

Policing of this realm of pure feeling is no longer exclusively pursued by means of the law, but also increasingly located outside the realm of the law. Methods of torture range from sensory deprivation to radical exposure to heavy metal music. The crisis of representation paradoxically doesnt diminish its power - just its predictability. The law is still as important as the nation and both wholeheartedly join in the efforts of policing the senses. The Empire of Senses doesn"t mean, that signs are no longer powerful. It just means, that you never know how and when they exercise this power.

\section{Political Aesthetics?}

The crisis of political representation makes clear, why the solution which Rancière proposes to the aesthetics of police has been undermined by the aesthetics of the Empire of Senses. According to Rancière, the police intervenes into the sensible mainly by excluding people from the realm of visibility and speech and therefore preventing their political

\footnotetext{
10 Peter Weibel, Über den Ikonoklasmus der modernen Kunst, in:http://hosting.zkm.de/icon/stories/storyReader\$33 Date of quotation 30.06.07
} 
representation. Political activity consists in making visible the invisible and creating speech out of noise. ${ }^{11}$ But the problem is, that within the Empire of Senses everything is nowadays visible and every speech has been turned into noise. Rancière imagined, that this could take place within a radical restructuring of the sensible as such, a messing up of this order of police in form a disagreement - and that would indeed be a political act. ${ }^{12}$ But the integration of the excluded into social visibility doesn"t any longer mean that the distribution of the sensible is affected in its structure. Within an economy based on the production of novelty and difference, cultural representation is no longer automatically linked to political representation. Cultural or aesthetic representation simply means to be integrated into an economy of difference or into spectacle as such. Its connection to political representation, which has been always shaky is absolutely unguaranteed. A political aesthetics as Rancière conceived it, has to be rearticulated in a situation of constant overvisibility, where the connection between political and cultural representation has become erratic.

But what could art do about this situation, when the police has wrestled its own tools from its hands? Until now art has done surprisingly little. It seems to have surrendered the realm of aesthetics to homeland security and public relations. But which understanding of aesthetics could help us to come to the rescue of our senses as subjects of Empire? Let's look again at different readings of monochromes. Alain Badiou interprets Malevich's monochrome Suprematist composition: White square on white ground as expression of a passion of the real of the 20th century. ${ }^{13}$ The desire of the real necessarily creates suspicion. The more real things are supposed to be, and the more authentic and genuine, the more suspicious they become. The passion of the real creates the drive to purge and to eliminate mere appearance, fake believers, traitors and so-called parasites. Badiou describes Malevich's painting as climax of the gesture of purge. Color is eliminated, form is eliminated, almost everything is eliminated in order to maintain the purity of feeling. To put it brutally: Malevich's White Square on White Ground could be read as the cleanliness after the

\footnotetext{
${ }^{11}$ Jacques Rancière, Das Unvernehmen, Frankfurt am Main: Suhrkamp, 2002. p. 41: Die politische Tätigkeit „,...lässt sehen, was keinen Ort hatte gesehen zu werden, lässt eine Rede hören, die nur als Lärm gehört wurde."

12 Rancière, ibid. p. $41 \mathrm{ff}$

${ }^{13}$ Alain Badiou, Das Jahrhundert, Zürich: Diaphanes, 2006, p. 70ff.
} 
purge, after the elimination of traitors and enemies of the people. The "pure feeling" that Malevich wanted to express, could refer to the feeling of suspicion and the over-whelming desire to clean the slate and to kill any opponents. But as Badiou remarks, there is one little difference which is being maintained within the overwhelming whiteness: the difference between form and ground as well as the tiny difference between white and white. ${ }^{14} \mathrm{~A}$ vanishing difference which reminds us, that reality does not lie in purity, but in the impossibility to attain it. Seen from this perspective, Malevich's monochrome is not about destruction but about subtraction; it is not about identity but about the evanescent tiny difference, which prevents identity and thus alone is real.

\section{Visual Realism}

But how could we apply this point of view to the current politics of the monochrome, to the Empire of senses with its general alert? How could we insert an imperceptible subtraction into the red lights which are flashed at us to evoke terror and destruction? Let's look at another monochrome by Malevich from the year 1915.

The painting Red Square. Visual Realism of a Peasant Woman in Two dimensions gives us a hint. By introducing a difference between figure and ground, and a tiny difference in the form of the square, Malevich turns a red shape into the visual realism of a peasant woman. Why is this picture realist? Because it does not show the woman but her difference from the overall group of peasants she belongs to. She does not represent peasants as such, and this real difference is expressed by the monochrome. The realism of the monochrome does not refer to any identity, but derives from the fact, that there is always to be a split between her and her representation, that she is irrepresentable as peasant. This difference is what we see. The unbridgeable difference between her and the red collective evoked by the square is subject of the monochrome. And this is what makes the painting deeply realist. But how can we read the red alerts flashed at us as something not pertaining to the paradigm of purge and destruction, but to the one of subtraction? We shouldn't interpret them as likenesses of our world or as icons of terror, stimulation and total immersion. But we should introduce one

14 Ibid. 
tiny little difference into our own perception. Let's read them as realist portraits, as Malevich did. Let's read them, not as portraits of peasant women, but as portraits of Abe Sada's contemporary successor, a nameless Thai woman, who was trafficked into forced sex work in Japan a few years ago. After enduring a few months of forced labor she had her female pimp killed with a beer bottle. ${ }^{15}$ Let's read the ubiquitous red alerts as a visual realism of her and her colleagues everywhere in the world; as a documentary picture of how they elude representation and representation eludes them. They have left the frame of the nation state behind and are afloat in an Empire of Senses, built on affect and sensation, which gushes through the fissures of states as well as through our own nervous systems.

Let's read the red alerts, the incessant discourse about security and threat, as a crisis of their political and aesthetical representation and simultaneously as the only realist strategy to visualize their dilemma. Let's see them as a realist portrait of a necessary insurrection against an Empire of Senses that tries to purge all difference by means of a dictatorship of affect and noise. It's time we feel it differently.

This text first appeared in Transversal 09/07: Art and Police, 2007 Published by eipcp - European

\footnotetext{
15 Lisa Katayama, Spirited away. In: http://metropolis. co.jp/tokyo/673/feature.asp „Between September 1991 and February 1994, there were five other cases in which trafficked Thai women committed murder out of desperation. " Date of quotation 28.06.07
} 
